\title{
Morphological Diversity in Inbred Lines of Maize (Zea mays L.)
}

\author{
Ajay Kumar*, Ashish Narayan and Kavita \\ Department of Plant Breeding and Genetics, Tirhut College of Agriculture, Dholi-843121, \\ Dr. Rajendra Prasad Central Agricultural University, Pusa, Bihar, India \\ *Corresponding author
}

\begin{abstract}
A B S T R A C T
The genetic diversity of maize inbred lines were analyzed by using $\mathrm{D}^{2}$ statistics during kharif, 2015 in Randomized Block Design (RBD) at TCA, Dholi farm of Dr. Rajendra Prasad Central Agricultural University, Pusa, Bihar, with eighteen inbred lines of maize

Keywords

Maize, Inbred lines, Genetic diversity,

Clustering, Quantitative characters

Article Info

Accepted: 07 October 2018 Available Online: 10 November 2018 derived from different maize populations. Results indicated that ANOVA for mean sum of squares due to inbred lines were significant for ten characters except for days to flowering, days to brown husk and girth of ears, indicating scope for selection of promising genotypes for yield improvement. The genetic divergence on the basis of ten quantitative characters was analyzed using Mahalanobis $\mathrm{D}^{2}$ statistics. All the genotypes were grouped into five clusters. The average intra cluster distance ranged from 1.91 to 4.23 . The maximum intra cluster distance was observed in cluster V (4.23). The highest inter cluster distance was observed in between Cluster I and V (36.99), followed by cluster I and IV (31.91), Cluster I and II (23.67), Cluster III and V (15.89), Cluster III and IV (13.56). Inbred lines from these clusters may be selected as parents for hybridization programme for developing new hybrid combinations. Ear height, ear length, ear girth, number of kernel rows per ear and grain yield showed maximum values in cluster $\mathrm{V}$, therefore, selection of parents from cluster $\mathrm{V}$ may be done for desired traits. Percent contribution of number of kernels/row $(60.78 \%)$ to total divergence was found maximum.
\end{abstract}

\section{Introduction}

Evaluation of genetic diversity is pre-requisite for identifying promising parents for any hybridization programme in plant breeding. In order to utilize the material for hybrid development, it is imperative to know the extent of diversity present among the inbred lines of maize. Most of the modern inbred lines used in maize hybrid programmes are second, third or fourth cycle lines that were developed from other inbred lines or from synthetic populations derived from crossing the inbred lines. The present investigation was carried out to know the magnitude of diversity present in these recently developed maize inbreds for yield components to select diverse parents for its further use in heterotic crosses and wide array of combinations.

\section{Materials and Methods}

The experiment was conducted during kharif, 2015 at TCA, Dholi farm of Dr. Rajendra Prasad Central Agricultural University, Pusa, Bihar, with eighteen inbred lines of maize 
derived from different maize populations. The plot had a uniform topography, fertile and well-drained soil. The experiment was conducted in Randomized Block Design (RBD) with 3 replications having plot size of $6.0 \mathrm{~m}^{2}$. Each plot consisting of two rows of $4 \mathrm{~m}$ length spaced at $75 \mathrm{~cm}$ row to row and 25 $\mathrm{cm}$ plant to plant, respectively. The observation during present investigation were recorded on five competitive plants were randomly taken from each plot in each replication for recording data of the traits, namely plant height, ear height, ear length, ear girth, number of kernel rows per ear and number of kernels per row.

However, traits like days to $75 \%$ tasseling, days to $75 \%$ silking, days to $75 \%$ brown husk and yield were recorded on plot basis. The genetic divergence among maize inbred lines was assessed by employing Mahalanobis $\mathrm{D}^{2}$ analysis based on quantitative characteristics and grouped as Tochers clustering pattern described by Rao (1952).

\section{Results and Discussion}

The analysis of variance was carried out to partition the total variance in to variance due to genotype and other sources for all characters. The results of analysis of variance for ten characters in maize inbred lines have been presented in table 1 revealed that mean sum of square due to inbred lines were significant for ten characters except for days to flowering, days to brown husk and girth of ears, indicating presence of ample amount of variability present among the treatments for the characters under study.

In the present investigation, the genetic divergence among eighteen inbred lines of maize on the basis of ten quantitative characters were analyzed using Mahalanobis $\mathrm{D}^{2}$ statistics and Tocher's clustering pattern and were presented in table 2 to 5 , respectively.
All the genotypes were grouped into five clusters. Cluster I had six genotypes viz., (CML161/CML-165)-BBB-11-BBB/CML193,(Pool33C23 (SubTINTY FQPM)-B-57BB/CML-193, CML-169, PoP-61, LM-13, WNC DMR 19 RYS FWS 1813, Cluster II had five genotypes viz., CML-165, S99S1 YQ-BBB-5-BB-B/CML 193, WNC DMR 11 R 4776, (CML 161×CML 451)-B-16-1-BB-2B/CML 193, (Pool 18 Seq $(5 \times$ G118) HS\#471-2-1-1-B/CML 193, Cluster III includes three genotypes viz., (Pool34C24 (SubTINTY DQPM)-B-20-BB/CML-193, HKI-586, CML373, whereas digenotypic Clusters i.e Cluster IV have genotypes namely CML-161, WNC DMR 11 R 27290 and Cluster V includes S99TLYQ (HG-AB) - BBB-54-BBB-54BBB/CML-193, PoP61C1QPMTEYE-51-2-12-B-1-13/CML-193, respectively. The genetic divergence among eighteen inbred lines of maize was subjected to hierarchial clustering which divided the inbred lines into five clusters according to their genetic distance. Geographical and genetic diversity exhibited no correspondence between them as genotype from different geographical region are grouped together, which might be due to free exchange of genetic material from different regions. Similar approach was adopted earlier by Singh et al., (2005), More et al., (2006), Bhoite and Dumbre (2007), Farzana Jabeen et al., (2007), Marker and Krupakar (2009), Pradhan, et al., (2009), Ganesan, et al., (2010), Kumar, et al., (2011), Reddy et al., (2012) and Alam et al., (2013) in maize. The average intra cluster distance range from 1.91 to 4.23. The maximum intra cluster distance was observed in cluster V (4.23), followed by cluster III (3.22), Cluster II (2.61) and Cluster IV (2.03). The minimum intra cluster distance was observed in Cluster I (1.91). The highest inter cluster distance was observed in between Cluster I and V (36.99), followed by cluster I and IV (31.91), Cluster I and II (23.67), Cluster III and V (15.89), Cluster III and IV (13.56). 
Table.1 Analysis of variance for ten characters in Maize inbred lines

\begin{tabular}{|c|c|c|c|c|}
\hline \multirow{2}{*}{$\begin{array}{c}\text { SI. } \\
\text { No. }\end{array}$} & \multirow[t]{2}{*}{ Characters } & \multicolumn{3}{|c|}{ Mean sum of square due to } \\
\hline & & Replication & Treatment & Error \\
\hline 1. & Days to $75 \%$ tasseling & 9.46 & 6.52 & 12.74 \\
\hline 2. & Day to $75 \%$ silking & 12.05 & 8.43 & 10.11 \\
\hline 3. & Day to $75 \%$ brown husk & 6.79 & 11.45 & 9.38 \\
\hline 4. & Plant height $(\mathrm{cm})$ & 329.85 & $564.68^{*}$ & 163.56 \\
\hline 5. & Ear height $(\mathrm{cm})$ & 144.68 & $166.34 *$ & 62.48 \\
\hline 6. & Ear length $(\mathrm{cm})$ & 0.29 & $4.56 * *$ & 0.61 \\
\hline 7. & Ear girth $(\mathrm{cm})$ & 0.52 & 1.22 & 1.16 \\
\hline 8. & Number of kernel rows/ear & 0.22 & $2.86 * *$ & 1.47 \\
\hline 9. & Number of kernels/row & 2.57 & $62.68 * *$ & 2.01 \\
\hline 10. & Grain yield (kg/ha) & 148862.90 & $1015712.97 * *$ & 134643.03 \\
\hline
\end{tabular}

Table.5 Percent contribution of characters towards genetic diversity

\begin{tabular}{|c|l|c|c|}
$\begin{array}{c}\text { SI. } \\
\text { No. }\end{array}$ & \multicolumn{1}{|c|}{ Source } & Times Ranked 1 & Contribution \% $^{\text {st }}$ \\
\hline $\mathbf{1}$ & Days to 75\% Tasseling & 0 & 0.00 \\
\hline $\mathbf{2}$ & Days to 75 \% Silking & 1 & 0.65 \\
\hline $\mathbf{3}$ & Days to 75\% Brown Husk & 5 & 3.27 \\
\hline $\mathbf{4}$ & Plant Height $(\mathrm{cm})$ & 11 & 7.19 \\
\hline $\mathbf{5}$ & Ear Height $(\mathrm{cm})$ & 1 & 0.65 \\
\hline $\mathbf{6}$ & Ear Length $(\mathrm{cm})$ & 31 & 20.26 \\
\hline $\mathbf{7}$ & Ear Girth $(\mathrm{cm})$ & 2 & 1.31 \\
\hline $\mathbf{8}$ & Number of Kernel Rows/ Ear & 2 & 1.31 \\
\hline $\mathbf{9}$ & Number of kernels/ row & 93 & 60.78 \\
\hline $\mathbf{1 0}$ & Grain Yield (Kg/ha) & 7 & 4.58 \\
\hline
\end{tabular}


Table.2 Clustering of eighteen Inbred Lines of Maize on the basis of $\mathrm{D}^{2}$ statistics

\begin{tabular}{|c|c|c|}
\hline Clusters & $\begin{array}{l}\text { No. of genotypes } \\
\text { within clusters }\end{array}$ & Genotypes in cluster \\
\hline I & 6 & $\begin{array}{l}\text { (CML 161/CML-165)-BBB-11-BBB/CML-193, (Pool } 33 \text { C 23(SubTINTY FQPM)-B-57-BB/CML-193, } \\
\text { CML-169, PoP-61, LM-13, WNC DMR } 19 \text { RYS FWS } 1813\end{array}$ \\
\hline II & 5 & $\begin{array}{l}\text { CML-165, S99S1 YQ-BBB-5-BB-B/CML 193, WNC DMR } 11 \text { R 4776, (CML 161×CML 451)-B-16-1-BB-2- } \\
\text { B/CML 193, (Pool } 18 \text { Seq (5×G 118)HS\#47-1-2-1-1-B/CML } 193\end{array}$ \\
\hline III & 3 & (Pool 34 C 24(SubTINTY DQPM)-B-20-BB/CML-193, HKI-586, CML-373 \\
\hline IV & 2 & CML-161, WNC DMR 11 R 27290 \\
\hline $\mathbf{V}$ & 2 & S99 TLYQ(HG-AB)-BBB-54-BBB-54-BBB/CML-193, PoP 61 C1 QPM TEYE-51-2-1-2-B-1-13/CML-193 \\
\hline
\end{tabular}

Table.3 Mean inter \& intra cluster distances among five clusters in eighteen Inbred Lines of Maize

\begin{tabular}{|l|c|c|c|c|c|}
\hline & I & II & III & IV & V \\
\hline Cluster I & $\mathbf{1 . 9 1}$ & 23.67 & 9.42 & 31.91 & 36.99 \\
\hline Cluster II & & $\mathbf{2 . 6 1}$ & 7.39 & 5.12 & 11.77 \\
\hline Cluster III & & & $\mathbf{3 . 2 2}$ & 13.56 & 15.89 \\
\hline Cluster IV & & & & $\mathbf{2 . 0 3}$ & 9.16 \\
\hline Cluster V & & & & & $\mathbf{4 . 2 3}$ \\
\hline
\end{tabular}

Table. 4 Cluster mean for ten quantitative characters in 18 inbred Lines

\begin{tabular}{|c|c|c|c|c|c|c|c|c|c|c|}
\hline & $\begin{array}{c}\text { Days to } \\
\mathbf{7 5 \%} \\
\text { Tasseling }\end{array}$ & $\begin{array}{c}\text { Days to } \\
75 \% \\
\text { Silkiing }\end{array}$ & $\begin{array}{c}\text { Days to } \\
\text { 75\% Brown } \\
\text { Husk }\end{array}$ & $\begin{array}{l}\text { Plant } \\
\text { Height } \\
\text { (cm) }\end{array}$ & $\begin{array}{c}\text { Ear } \\
\text { Height } \\
\text { (cm) }\end{array}$ & $\begin{array}{c}\text { Ear } \\
\text { Length } \\
\text { (cm) }\end{array}$ & $\begin{array}{l}\text { Ear } \\
\text { Girth } \\
(\mathrm{cm})\end{array}$ & $\begin{array}{c}\text { No. of } \\
\text { Kernel } \\
\text { Rows/ Ear }\end{array}$ & $\begin{array}{l}\text { No. of } \\
\text { kernels/ } \\
\text { row }\end{array}$ & $\begin{array}{c}\text { Grain } \\
\text { Yield } \\
\text { (Kg/ha) }\end{array}$ \\
\hline Cluster I & 58.00 & 61.28 & 86.28 & 122.00 & 51.00 & 15.72 & 13.11 & 11.56 & 19.78 & 1400.75 \\
\hline Cluster III & 58.00 & 61.22 & 86.67 & 113.33 & 57.78 & 16.22 & 13.33 & 12.67 & 24.89 & 1853.79 \\
\hline Cluster IV & 55.67 & 58.83 & 84.33 & 146.50 & 64.00 & 18.67 & 13.83 & 13.33 & 29.83 & 2396.88 \\
\hline Cluster V & 58.50 & 62.17 & 87.00 & 110.67 & 72.83 & 19.00 & 15.00 & 14.00 & 28.33 & 3010.56 \\
\hline
\end{tabular}


Similarly the lowest value of inter cluster distance was observed in between Cluster II and IV (5.12), followed by Cluster II and III (7.39), Cluster IV and V (9.16) and Cluster I and III (9.42). On the basis of these intra and inter cluster distances it is observed that maize inbred lines grouped together were less divergent than the inbred lines which fall into different clusters as reported earlier by Farzana Jabeen et al., (2007), Nehvi et al., (2008), Patel et al., (2009), Pradhan et al., (2009), Alam and Alam (2009) and Gupta and Singh (2011) in case of maize.

Cluster mean in respect of ten quantitative characters of eighteen inbred lines of maize were presented in table 3 . From perusal of table, it was observed that cluster mean for days to $75 \%$ tasselling was minimum in cluster IV (55.67) but maximum in cluster II (59.27). Days to $75 \%$ silking was minimum in cluster IV (52.83) but maximum in cluster II (62.53), The cluster mean for days to $75 \%$ brown husk was minimum in cluster IV (84.33) and maximum in cluster II (87.47). Plant height cluster mean was minimum in cluster V (110.67) and maximum in IV (146.50). Ear height, ear length, ear girth, number of kernel rows per ear and grain yield showed minimum Cluster mean in cluster I (51.00, 15.72, 13.11, 11.56, 1400.75) but it showed maximum in cluster V (110.67, $72.83, \quad 19.00, \quad 15.00, \quad 14.00, \quad 3010.56)$ respectively. Number of kernels per row had minimum cluster mean in cluster I (19.78) and maximum cluster mean in cluster IV (29.83). These findings are in accordance with Singh et al., (2005), Pradhan et al., (2009), Marker and Krupakar (2009) and Alam and Alam (2009).

Percent contribution of ten quantitative characters to total divergence were found maximum for number of kernels/row (60.78\%) followed by ear length (20.26\%), plant height $(7.19 \%)$, grain yield $(\mathrm{Kg} / \mathrm{ha})$
(4.58), days to $75 \%$ brown husk (3.27\%), ear girth and number of kernel rows per ear $(1.31,1.31 \%)$, ear height $(0.65 \%)$ whereas days to $75 \%$ tasseling $(0.00 \%)$. Among 153 combinations, no. of genotype combinations ranked $1^{\text {st }}$ (93 time) for number of kernels/ row, followed by ear length (31 times), plant height (11 times), grain yield/ plot (7 times), days to $75 \%$ brown husk (5 times), ear girth and number of kernel rows/ ear (2 times) and also days to $75 \%$ brown husk (2 times) However, days to $75 \%$ tasseling had no contribution towards genetic divergence. Similar observation was recorded by Ganesan et al., (2010) and Nehvi et al., (2008) in maize.

\section{References}

Alam, M. A., Khan, A. A., M. R. Islam, K. U. Ahmed and A. B. M. Khaldun (2013). Studies on genetic divergence in maize (Zea mays) Inbreds. Bangladesh J. Agril. Res. 38(1): 71-76.

Alam, M. S. and Alam, M. F. (2009). Genetic divergence study of maize inbred lines (Zea mays L.). International Journal of Sustainable Agricultural Technology. 5(3): 28-31.

Astha Gupta and Singh, A. K. (2011). Studies on genetic diversity of certain inbred genotypes of maize (Zea mays L.) at Varanasi. Trends in Biosciences. 2011; 4(1): 63-65.

Bhoite, K. D. and Dumbre, A. D. (2007). Studies on genetic diversity in forage maize (Zea mays L.). Journal of Maharashtra Agricultural Universities. 32(2): 290-291.

Farzana Jabeen., Sahib, K. H. and Satyanarayana, E. (2007). Divergence studies in quality protein maize (Zea mays L.) genotypes. Research on Crops. 8(3): 609-611.

Ganesan, K. N., Nallathambi, G., Thura Safawo., Senthil, N and Tamilarasi, P. 
M. (2010). Genetic divergence analysis in indigenous maize germplasms (Zea mays L.). Electronic Journal of Plant Breeding. 1(4): 1241-1243.

Mahalanobis, P. C. (1936). On the generalized distance, Proc. Nat. Inst. Sci. (India), 11(1): 49-55.

Marker, S. and Krupakar, A. (2009). Genetic divergence in exotic maize germplasm (Zea mays L.). Journal of Agricultural and Biological Science. 4(4): 44-47.

More, A. J., Bhoite, K. D. and Pardeshi, S. R. (2006). Genetic diversity studies in forage maize (Zea mays L.). Research on Crops. 7(3): 728-730.

Nehvi, F. A., Makhdoomi, M. I., Vaseem, Yousuf, Bahar, F. A. and Sabeena, Naseer. (2008). Genetic divergence among local maize (Zea mays L.) cultivars of Kashmir Valley. Journal of Eco friendly Agriculture. 3(2): 130-133.

Patel, J. S., Vaghela, P. K., Patel, D. B., Parmar, D. J. and Macwana, S. S. (2009). Genetic divergence in baby corn
(Zea mays L.). Research on Crops. 10(3): 683-686.

Pradhan, K., Pradhan, B., Sarangi, D. N., Sial, P. and Mishra, T. K. (2009). Genetic divergence in newly developed inbred lines of maize. Environment and Ecology. 27(1): 219-221.

Rao, C.R. (1952). Advance statistical methods in biometrical research. John Wiley and Sons Inc., New York.

Reddy, V.R., Farzana Jabeen and Sudarshan, M.R. (2012). Genetic divergence in maize (Zea mays L.). Crop Research. 44(3):391-393.

Singh, P., Sain Dass., Dwivedi, V. K., Kumar, Y. and Sangwan, O. (2005). Genetic divergence studies in maize (Zea mays L.). Annals of Agri Bio Research. 10(1): 43-46.

Vinay Kumar, Singh, P. K. and Astha Gupta. (2011). Studies of genetic diversity in quality protein maize (Zea mays L.) inbreds. Current Advances in Agricultural Sciences. 3(2): 96-99.

\section{How to cite this article:}

Ajay Kumar, Ashish Narayan and Kavita. 2018. Morphological Diversity in Inbred Lines of Maize (Zea mays L.). Int.J.Curr.Microbiol.App.Sci. 7(11): 446-451. doi: https://doi.org/10.20546/ijcmas.2018.711.052 